\title{
Specificity of German-Russian Dictionary of Onomatopoeias
}

\author{
Svetlana Sergeevna Shlyakhova \\ Olga Valentinovna Shestakova
}

Perm National Research Polytechnic University, Komsomolsky Prospeckt, 29, Perm, 614000, Russia

Doi:10.5901/mjss.2015.v6n3s2p380

\section{Abstract}

The problems of lexicographical fixation of sound words (onomatopoeias) are revealed in the article. Here the specific features of the German-Russian dictionary of onomatopoeias, published by the authors, are described: phonosemantic principles of description of these language units, the structure of a dictionary entry, the criteria for selection of units, structure and composition of the vocabulary, field label system. The possibilities of practical application of the dictionary in phonosemantics, stylistics, etymology, as well as for translation and learning German as a foreign language are mentioned.

Keywords: lexicographical fixation, phonosemantics, onomatopoeia, sound words, dictionaries, German languages, Russian language.

\section{Introduction}

The advantage of the European and American phonosemantics is that the lexicographical work on phonosemantic units which are realized in dictionaries and lists [D'Elia, 1998; Fujita, 1984; Gomi, 1989; Kakehi, 1998; Magnus, 1999; McCune, 1983, etc.] is carried out there. English and Japanese languages are represented in lexicography most of all. Russian studies also have little experience of lexicographical fixation of onomatopoeias and interjections.

For lexicographical fixation of onomatopoeia the grammatical heterogeneity of the class of onomatopoeias should be considered, this class includes 1) grammatical classes which are traditionally sorted out (a verb, a noun, an adjective, and so on.), and 2) phonosemantic marginalia (interjections, onomatopoeias, words of call and chasing away of animals).

Fixation of grammatically «normal» onomatopoeias in the German and Russian lexicography is systematic and complete enough. The main problem is etymologizing of sound-imitative vocabulary. Sound-imitative nature of a word is observed only in obvious cases; more often the labels such as «suspicious», «disputable», «unclear» are made [Shlyakhova 2004].

Lexicographical fixation of phonosemantic marginalia, and wider - language anomalies (interjections, onomatopoeias, relatives, particles and so on) - is always a problem for lexicographers. N.R. Dobrushina writes that interjections have remained beyond the attention of lexicography [Dobrushina, 1995]. D. I. Kveselevich and V. P. Sasina say, that «in bilingual lexicography interjections and wider - relatives are clearly "unlucky". This is one of the least developed vocabulary layer in the lexicographic practice. <..> They are represented little in the dictionaries of onomatopoeia and verb and interjection words» [Kveselevich, Sasina, 2001, p. 8].

According to A.N. Baranov and I.M. Kobozeva, "conceptual apparatus developed to describe the logical particles $\langle\ldots\rangle$, appears ineffective for description of particles that do not participate or hardly participate in formation of the logical structure of a sentence (similar difficulties emerge with interjections )" [Baranov, Kobozeva, 1988, p. 46]. There is not less problematic situation in the description of onomatopoeias.

In the "Explanatory Combinatorial Dictionary of Modern Russian Language" [Melchuk, Zholkovsky, Apresian, 1984] and in the "Integral Dictionary" [Materials for the Integral Dictionary ..., 1991] there are samples of dictionary entries of certain Russian verbs, nouns, adjectives, adverbs, prepositions, particles and conjunctions. However, "almost the only representative class of words that are not covered in the lexicographic description of a new type is interjections" [Dobrushina, 1995]. Thus, the development of principles of lexicographic description of phonosemantic marginalia, selection of parameters relevant for the dictionary description is a problem of lexicography. 


\section{Experience of German-Russian Dictionary of Onomatopoeias}

\subsection{Practice of lexicographical fixation of onomatopoeia}

The Russian studies have experience of interjections fixation also in bilingual dictionary - English-Russian Dictionary of Interjections [Kveselevich, Sasina, 2001]. The dictionary contains about 1,000 units, 800 of which are interjections and relatives, but only 100 are onomatopoeias of Russian language. A dictionary article includes a header (interjection, relative, onomatopoeia, verb-interjection word), its interpretation (in most cases by Explanatory Dictionary of Russian language), offered English counterparts or equivalents, illustrative quotes from Russian literature, translation of these quotes into English [Kveselevich, Sasina 2001, 10]. But this dictionary does not take into account the specificity of units, including their oral existence.

Such units as akh, tolk, tuk are considered more sequentially in the dictionary of Russian phonosemantic anomalies, where over 1,500 dictionary entries are presented. The majority of the illustrations is the fixation of live oral speech. A dictionary article includes interpretation of meaning, grammatical labels (if necessary), phonosemantic characteristic, status labels (in the illustrative part), as well as the etymological part with reference to the common Slavic and/or Indo-European sound-imitative basis or root, which means a primary motivation of the word. In the absence of the etymology the semasiological and phonosemantic parallels in related and unrelated languages are given in the dictionaries. Certain entries include idioms with abnormal forms [Shlyakhova, 2004].

Thus, the Russian phonosemantic marginalia have got primary systemic lexicographic description.

The problems of fixation of phonosemantic marginalia in Russian lexicographic practice are also characteristic for description of German onomatopoeias. First of all, there is the lack of fixation in the dictionaries. In the most significant Dornseiff's Thesaurus Dictionary of German Language [Dornseiff, 2004] phonosemantic marginalia are not fixed. Currently, on the German material the German-English-Polish dictionary of verbs denoting the noises is being developed. These noises are: the sounds of knock, drop, shock, and the sounds of animals, etc. [Mischke, 2013].

Some onomatopoeias are not fixed in the explanatory dictionaries (brumm "the dog's growl, the chirring of insects"; ähm "exclamation, expecting the answerability, the call to communication"). The corps Wortschatz-Lexikon Uni Leipzig, Projekt Gutenberg, Corpus der Deutschen Sprache, Franklang, we study, give contexts with the meanings that are not marked in explanatory dictionaries: ach "sigh, groan", ha, ho "expiration" and others.

The next problem is the unsystematic nature and the inconsistency of grammatical labels. Since at present the grammatical status of onomatopoeias has not been determined in German language, they are usually designated in all dictionaries as interjections (Interjektion, Int), then follows the field label: lautmalend, lautm (sound word). So, bam $<$ Interj.>. lautm. für einen dunkleren [Glocken] klang [Duden]. At the same time the evident sound imitation may not have the label lautmalend, lautm. So, hopp "the sound of walking, movement; stamping" is presented as part. (Partikel) "a particle and serves for rousing to action" [Duden].

However onomatopoeias form an independent part of speech other than interjections: 1) interjections express feelings, emotions and desires, without naming them, but onomatopoeia do not express them; 2) interjections need context, facial expressions or accompanying intonation, but onomatopoeia are understandable without explanation; 3 ) interjections are attitude words, but onomatopoeias have lexical meaning; 4) onomatopoeias unlike interjections are widely used in word formation [Kurashkina, 2007, p. 11].

It is obvious, that the original interjections (ach, ha "exclamation of surprise"; hu "exclamation of horror, disgust"), children's words (baba "a sound of lulling a child to sleep", ata gehen "going for a walk"), onomatopoeias (knips "sound of clicking", knicks "crackle, crack") and derivatives interjections (Donnerwetter, Gott) have a different nature. However, all of them are qualified in German grammar and dictionaries as Interjektion.

In etymological dictionaries the sound imitative origin of the evident explicit onomatopoeias is not always indicated as well:

Mid. German heidi in German Dictionaries [Duden, 2001; EWDS, 2002] sound imitative nature is not marked: heidi int "exclamation to denote the rapid movement". Sie setzten sich auf den Schlitten, und [ab] heidi ging's den Berg hinunter; heida int landsch. "denotes and/or indicates the emotional state of wonder, amazement, praise, approval". Heida, ist das ein Rennen! Heida, war das eine Fete! In the dictionary of Fasmer M. the word aida, haida is "an interjection, expresses exclamation, urging the animals", i.e. its imitative nature is also not marked [Fasmer].

\subsection{Problems of lexicographical fixation of onomatopoeia}

Analysis of lexicographic fixation of onomatopoeia shows that lexicography is the section of Germanic and Russian 
Studies, which did not pay enough attention to sound imitation as such. Lexicographic problems associated with fixation of onomatopoeia are:

1. Lack of specialized dictionaries. On the Russian material, according to our data, there are only two dictionaries [Kveselevich, Sasina, 2001. Shlyakhova, 2004], which include not entire corpus of onomatopoeic words, but only phonosemantic marginalia. On the German materials German-English-Polish dictionary of verbs denoting noises is being developed [Mischke, 2013].

2. Insufficient and non-systemic lexicographical fixation. Some German and Russian onomatopoeias are not fixed in the dictionaries. Marginalia obtain more complete fixation in Russian studies.

3. Indistinct system of field labels; undifferentiated onomatopoeias, interjections and sound symbolic words. In German and Russian practice interjections and onomatopoeias do not differ; they are combined into one class. Usually in dictionaries they have the following field labels: Interjektion / interjections, sometimes the labels lautmalend / onomatopoeia.

4. Lack of etymological development of this lexical layer. In German etymological dictionaries the sound imitative nature of primary interjections is not usually marked (äh, au, o, oh etc.): they are characterized as exclamations in certain emotional states. In Russian etymological dictionaries the sound imitative origin of primary interjections is usually marked, but not always.

5. Lack of clear criteria of comparison in bilingual dictionaries. Comparison of sound imitative vocabulary in German-Russian dictionaries is based on their semantic proximity, at the same time phonosemantic specificity of these units is not taken into account. So, the word bum is qualified in the dictionaries (Lingvo, Multitran. Big German-Russian Dictionary) as an interjection (Interjektion) and translated as boom, bakh. Meanwhile in this meaning bum is an onomatopoeia (not interjection) and explicates a blow (it is expressed by explosive /b/) followed by a lack of tonal accent (expressed by a sonant $/ \mathrm{m} /$ ). The translation of bakh is not entirely exact, as here the acoustic denotation is a blow followed by a lack of acoustic accent (expressed by a voiceless guttural ( $\mathrm{x} /$ ). Consequently, the Russian bakh taking into account phonosemantic features will correspond to the German baff or paff.

Translation of onomatopoeias is made on the basis of semantic and grammatical criteria, while correlation of the sound cover of a unit with its content (principally meaningful feature) is not considered.

\subsection{General data of a dictionary}

From our point of view, the creation of the German-Russian phonosemantic dictionary is an urgent problem of not only phonosemantics, but also of Germanic and Russian Studies in general. Even a simple fixation of the words of sound imitative origin established within the classical (not phonosemantic) etymology, will allow imagining what a considerable place onomatopoeia takes in the German lexical fund.

The problem of fixation and description of onomatopoeias is partially solved within our German-Russian dictionary of onomatopoeias [Shlyakhova, Shestakova, 2011].

In the dictionary the history of the study of German sound imitation is considered, the problem of lexicographic fixation of onomatopoeias is researched, the basis of units definitions as primarily motivated are defined, phonosemantic typology of German onomatopoeia is offered, the phonosphere and its reflection in the German language is presented in its most general form.

Informational, systematizing, regulatory, educational are the main functions of the dictionaries [Denisov, 1980]. Our dictionary fulfills the informational (intended for specialists in Phonosemantics, lexicology, translators and all those who study German language), systematizing (a system of meanings of German onomatopoeias, their semantic links) and educational (effectiveness in the study of language) functions.

The dictionary can be attributed to the dictionaries of descriptive type, a dictionary entry of which includes the following components: a lexical entry (a vocable), variants, a label of the sphere of use, grammatical information, interpretation, usage examples, examples of non-standard uses, a zone of idiomology (set expressions, idioms) [Baranov, 2001].

The dictionary presents the basic fund of German onomatopoeias, offers material for etymologizing of certain lexemes, allows us to follow the development of individual linguistic units, not only in the framework of Roman-Germanic, but also Indo-European languages. The dictionary apparently is the first attempt of systemic lexicographic description of the German onomatopoeias recorded in different socio-functional strata of German speech.

The main purpose of the Dictionary is the initial, and therefore only very approximate establishment of German onomatopoeias fund (in comparison with Russian), which explicate phonosphere in German language. 
The dictionary includes onomatopoeias, functioning in German language, as well as their Russian correlates. Furthermore, the Dictionary includes the idioms and phraseological units where onomatopoeia is the base component. The dictionary contains about 1,100 entries, which are distributed in 210 phonosemantic groups. A group contains from 1 to 30 entries. Header units of the nests are phonosemantic marginalia, in traditional Russian grammatical terminology onomatopoeias, interjections, verbal-interjection forms, words of cry and chasing away the animals, etc., in the German tradition - interjective.

The main criterion of the selection of units is their primary motivation: the possibility of inclusion of units into the German language sound imitative system based on universal classification of onomatopoeias; sound imitative etymology in one of the etymological sources; "sound" meaning of the word, which indicates the acoustic denotation.

\subsection{Principles of comparison of materials.}

The following phonosemantic and grammatical (taking into account phonosemantic features) categories of comparison of onomatopoeias were used in the dictionary:

1) acoustic feature: for example, compactness, diffusivity of the spectrum of the vowel (/a-i/), correlating with the symbolic meaning of big-small size, etc.): Germ. bam - Russian bam "a low bell sound"; Russian bim and Germ. bim "a high bell sound";

2) phoneme type: thus, the meaning of "to tinkle, crack" in different languages include a plosive and/or vibrant/sonorant: Dutch. kletteren, Finn. kalahtaa, Estonian. kõlksatus "to clank"; Icelandic skrölt, Macedonian клопот, Norwegian skrangle, Turkish çıngırak, Russian. drr, trrr - Germ. klirr;

3) root morpheme of specific acoustic-articulatory structure: instants: Germ. patsch - Rus. chap, chak, chik "the sound of impact, knock"; continuants: Germ. piep - Rus. pi-pi "peep"; frequentatives: Germ. krach, pratsch, raps - Rus. briak, hriap, trah"an impact sound";

4) fonestema: thus, semantic feature "to crack" in German has an initial sound /kn/: knack(s), knick(s), Knall; for the Russian language the initial sounds / $\mathrm{hrl}$, Itrl are typical: crunch, crackle;

5) interjection: Germ. ach, oh - Rus. ax, ox "exclamation of joy, astonishment, surprise, etc."; Germ. äks (bäks) Rus. be, bis "exclamation of disgust";

6) onomatopoeia: Germ. gluck - Rus. bul'k "the sound of liquid motion"; kling - Rus. cling "the sound of impact the glass surfase"; Germ. platsch - Rus. bultih "the sound when dropped in the water";

7) the words of cry and chasing away of animals and birds: Germ. husch - Rus. kish, kshsh "a cry, by which birds, pets are chased away, etc.";

8) The categorematic parts of speech on the basis of phonosemantic marginalia: Germ. muhen - Rus. michat' (a cow), Germ. bähen - Rus. bleiat'; Germ. Bimbam - Rus. zvon, trezvon; Germ. heulen - Rus. uhat" (an owl);

9) set expression, idiom, phraseological unit, paroemia: Germ. Larifari - Rus. lia-lia fa-fa "idle talk"; Germ. Maul halten - Rus. rot zatkni; Germ. Er sagt weder gicks noch gacks - Rus. Он ни мьчит, ни телится; Germ. Rotz und Wasser heulen - Rus. Выть белугой; реветь в три ручья; Germ. ins Maul schmieren - Rus. Разжевать и в рот положить, etc..

However, not all words find their correlates in the languages compared on the basis of the criteria specified above, which is on the one hand due to the specificity of the phonetic system of a language, on the other hand to the phonosemantic law of nomination multiplicity (one and the same denotation can be nominated by various factors or by completeness / incompleteness of linguistic explication of a kineme).

Thus, in Germ, blaff and Russ. tiav-tiav, gav-gav, av-av the initial component of articuleme (perceptually hardly disarticulated for people) is differently presented in Russian (front and back) and in German (labial, lateral), but the final element of articulation is explicated equally (back vowel + labio-dental). In Russian a-p-chhi (ahchoo) all stages of kineme are explicated (mouth opening - closure - exhale), and in chihat' (to sneeze) - only the last stage. In Germ. hatschi "sneezing sound", nieseln "to sneeze". Nieseln is also a sound imitative verb, where the initial stage - sniff is presented.

Germ. Bähschaf "a fool" (< bäh "baa, sheep bleating" + Schaf "a sheep") is motivated by characteristics and sounds of an animal, and the Rus. durak (a fool) (< Common Slavonic *dur-b is connected with *du-ti "to blow") is motivated by the sign of «pout». The difference of features taken as a basis of the nomination in different languages does not allow giving adequate phonosemantic correlates. In this case, the relevant correlate on the phonosemantic basis will not be durak (a fool), but slang, colloquial ovtsa, baran (sheep, ram), which is also based on the characteristic features of the animals and is a primary motivated.

In all the above cases, the comparison in the Dictionary is based on partial phonosemantic compliance based on common associations. Compare "Piercing-cutting" semantics: Germ. Die Klingen kreuzen "cross swords", measure 
strength (in a dispute) "- Russ. рубиться, резаться на словах (to fight in word) "to argue" (colloquial); Обмен колкостями (the exchange of barbs) "dispute". These approaches to the description of onomatopoeia will allow finding more accurate comparison in translation practice, even in the absence of the required unit in the Dictionary.

Thus, comparison of materials in the Dictionary is performed on the basis of universal and specific phonosemantic features

1) universal phono-semantic features: a) acoustic feature (Germ. bam - Russ. bam, Germ. bim - Russ. bim); b) phonemic identity (Germ. bäh - Russ. be, Germ. bum - Russ. bum, Germ. hihi - Russ. khi-khi, Germ. kikeriki - Russ. kukareku, Germ. piep - Russ. pip); c) phonestheme identity (Germ. plumps - Russ. plukh;

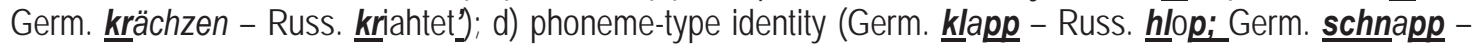
Russ. schelk);

Table 1. Universal phono-semantic features

\begin{tabular}{|c|c|c|c|}
\hline \# & Feature & German Language (examples) & Russian Language (examples) \\
\hline 1. & acoustic feature & $\begin{array}{l}\text { bam } \\
\text { bim }\end{array}$ & $\begin{array}{l}\text { bam } \\
\text { bim }\end{array}$ \\
\hline 2. & phonemic identity & $\begin{array}{c}\text { bäh } \\
\text { hihi } \\
\text { kikeriki } \\
\text { piep }\end{array}$ & $\begin{array}{c}\text { be } \\
\text { khi-khi } \\
\text { kukareku } \\
\text { pip }\end{array}$ \\
\hline 3. & phonestheme identity & $\begin{array}{l}\text { plumps } \\
\text { krächzen }\end{array}$ & $\begin{array}{l}\text { plukh } \\
\text { kriahtet' }\end{array}$ \\
\hline 4. & phoneme-type identity & $\begin{array}{l}\text { klapp } \\
\text { schnapp }\end{array}$ & $\begin{array}{l}\text { hlop } \\
\text { schelk }\end{array}$ \\
\hline
\end{tabular}

2) specific (idioethnic) phonosemantic features: a) phonestheme linguistic specificity: the meaning of "to crack" in German is expressed by initial phonestheme $\mid \mathrm{knl}$ - knack(s), knick(s), in Russ. Ihrl, Itrl - xpycm, треск; b) sound imitative motivation and sound imitative etymology with a similar semantics (Bähschaf баран, овца (ram, sheep); die Klingen kreuzen - рубиться (to fight)).

Table 2. Specific phono-semantic features

\begin{tabular}{|c|l|c|c|}
\hline$\#$ & Feature & $\begin{array}{c}\text { Gorman Language } \\
\text { (examples) }\end{array}$ & $\begin{array}{c}\text { Russian Language } \\
\text { (examples) }\end{array}$ \\
\hline 1. & phonestheme linguistic specificity & knack(s), knick(s) & xpycm, mpeck \\
\hline 2. & $\begin{array}{l}\text { sound imitative motivation and sound imitative etymology } \\
\text { with a similar semantics }\end{array}$ & $\begin{array}{c}\text { Bähschaf } \\
\text { die Klingen kreuzen }\end{array}$ & $\begin{array}{c}\text { бapaH, овца; } \\
\text { рубиться }\end{array}$ \\
\hline
\end{tabular}

\subsection{Vocabulary composition}

The dictionary includes onomatopoeias, functioning in German language, their Russian correlates, as well as idioms and phraseological units, where the base component is the onomatopoeia. The vocabulary is based on the corpuses of German, Russian, Slavic etymological, explanatory, slang dictionaries, scientific reference books and researches, as well as materials of Russian-language and German-language corpus-based linguistics.

\subsection{Vocabulary structure}

The dictionary contains over 1,100 entries, which are distributed in 210 phonosemantic groups. A group contains from 1 to 30 entries. The entries are arranged under the alphabetic-ran-on layout principle. The basis of the alphabetical arrangement is formed by the German alphabet. Each phonosemantic group consists of German and Russian parts. Header units of the group are phonosemantic marginalia, including replications (hihi, toitoi) and triplications (blablabla), ablaut dyads (klipp-klapp; klitsch-klatsch; ritsch-ratsch; rips-raps) and rhymed formations (holterdiepolter, kladderadatsch, schwuppdiwupp ), etc. The words derived from these marginalia are included in the structure of a group. Russian equivalents are given for the words. 


\subsection{The Structure of a dictionary entry}

A headword of a group differs from the headwords that are the components of the group with the presence of etymological reference in it. The dictionary entry of a headword of a group includes: 1) a headword; 2) an etymological part: indication of the sound imitative base or root, which indicate the primary motivation of the word; in the absence of the sound imitative etymology the semasiological phonosemantic parallels in related and unrelated languages are presented in etymological dictionaries; specification of the source of these etymologies; 3) a dictionary entry. The system of meanings of each onomatopoeia is presented within four groups, which are marked by Roman numerals: I - acoustic; II - articulatory, and the sounds produced by animals; III - onomatopoeias of speaking, and the words of call and chasing away; IV - "non-sound" meanings formed on the basis of onomatopoeias.

I) Acoustic onomatopoeias, which are defined as words producing by phonemic means the non-articulatory acoustic sounds of external environment (blaff "a sound of impact, fall, push, бyx, бax", bam "a low bell sound").

II) Articulatory onomatopoeias (Phono-intra-kinemes), which nominate sound processes occurring in the nasal, mouth and throat cavity of people: reflective (accompanying these or those feelings) and "expressive" (accompanying emotions) movements (hatschi "sneezing sound"; Happ $m$ "grasping (by teeth, mouth), and also imitation of the voices of birds and animals, the nomination of their "speaking" (blaff "dogs barking, gav, av, tiav, tiaf").

III) Onomatopoeias of speaking are units reproducing by phonemic means non-reflective acoustic-articulatory sounds characterizing the process of speech, speaking in isolation from the concrete sense of the speech, presenting the speech process in its target, modal, physiological, acoustic, and other characteristics (blaffen "to talk fast, chatter, rattle") and the words of call and chasing away of animals and birds (put "The words calling hens, chickens"; husch "a cry, which scares birds, pets away etc.")

IV) "Non-sound" meanings formed on the basis of onomatopoeia (Bambule 1) "ballyhoo (riots, disorders in the prison or correctional institution); 2) "noisy meeting, the party"; Put "small fry"; Happen "a piece, small sized snack"; Blaffer "dog, mutt").

\subsection{Dictionary labels}

The dictionary description includes the grammatical, stylistic and functional-phonosemantic labels.

Grammatical labels are conditioned by the specificity of the German language: they indicate the identity of a particular part of speech, control of verbs, auxiliary verbs (to form complex forms of the past tense, etc.). These labels allow making a distinction between the onomatopoeias and nouns, adjectives, interjections (interjectives), particles. For example, Ach n "complaints, oohs and aahs", ach lautm. (onomatopoeia) "sigh"; ach int (interjective) "ah"; Schlapp m "aslap; impact", schlapp lautm. "a thud on elastic", schlapp adj "languid; weak".

Functional-stylistic labels indicate the sphere of onomatopoeia existence. Compare brumm lautm. kinderspr. (Kindersprache) "machine", Brummer m ugs. (Umgangssprache) "hefty truck", "prison", "manure fly", brummfrei adj tech. (Technik)" free of alternating current hum".

Phonosemantic labels reveal the main point of the German onomatopoeia. Four groups in the framework of which each onomatopoeia is represented, are designated by Roman numerals: I - acoustic onomatopoeias; II - articulatory onomatopoeias; III - onomatopoeias of speaking; IV - "non-sound" meanings formed on the basis of onomatopoeias. The labels lautm., Int, att. (attractant), repp. (repellent) allow making a distinction between the onomatopoeias, interjectives, calling words and chasing away words: Compare brr "бpp" lautm. "Motor noise", int "denotes and / or indicates a state of physical discomfort; anxiety; disgust"; husch lautm. repp. "kish", int "unexpected and / or intense action, movement, and so on. shuh".

Table 3. Phono-semantic labels

\begin{tabular}{|c|c|c|c|c|}
\hline \multirow{2}{*}{ Meaning } & \multicolumn{2}{|c|}{ Label } & \multirow{2}{*}{ Meaning } & \multirow{2}{*}{ Label } \\
\hline & German Language & Russian Language & & \\
\hline Sound imitation (onomatopoeia) & onomatop. & lautm. & acoustic onomatopoeias & 1 \\
\hline interjections & int. & int & articulatory onomatopoeias + sounds, produced by animals & II \\
\hline attractant, calling word & call. & att. & onomatopoeias of speaking + calling and chasing away words & III \\
\hline repellent, chasing away word & chas. & repp. & «non-sound» meanings of onomatopoeias & IV \\
\hline
\end{tabular}


Thus, the labels allow you to see how onomatopoeias go to the category of systemically grammaticalized units, acquire interjection meaning, as well as provide an opportunity of correct grammatical and stylistic use in speech.

\subsection{Practical application of the dictionary}

This dictionary offers new material for lexicographic practice, introducing a great number of phonosemantic marginalia to scientific revolution.

The materials of the dictionaries can be used for the expansion in the etymology of the interpretative base of etymologizing of individual words, as well as lexicographical base of German and Russian dictionaries, which often deny the systematic fixation or adequate qualifications of phonosemantic labeled material.

This Dictionary can be successfully used in the practice of translation, since the description of onomatopoeias in the Dictionary is performed taking into account the specificity of phonosemantic and stylistic coloring of these units. Thus, the verb schnapsen has in dictionaries the label ugs.scherzhaft (joking), but in the traditional bilingual German-Russian dictionary it is translated by stylistically neutral Russian expression numь водку (to drink vodka). German Schnapsen in the Dictionary has a number of Russian Matches: шмякнуть, хлопнуть, шлепнуть, хлебнуть, клюнуть, клюкнуть, трахнуть, хлебнуть, шарахнуть, бухнуть, тяпнуть, тюкнуть, щваркнуть, хряпнуть, бахнуть, хлобыстнуть, дерябнуть, дербальзннуть, чебурахнуть, etc. These Russian correlates are also acoustic onomatopoeias and belong to colloquial speech. The large number of variants gives opportunity to make a more accurate translation.

The materials of the Dictionary will give opportunity to find more exact translation (based not only on the semantic, but on the phonosemantic similarity) for sound imitative units. Thus, Germ. quieken is translated by Russian numamb, визжать, whereas here Russian dialectal квикать, кувикать "squeak, whine" is phonosemantically closer, while the seme "пронзительный крик, визг, писк" (offered in the translation through визжать) is not supported by the phonetic structure of the word quieken. The word put "the calling words for hens, chickens" is translated as tsip-tsip, while phonosemantically closer it is translated as tip-tip In our opinion, such little things are important, because in this case the translation retains the familiar sound patterns of the source language.

The Dictionary can be successfully used for methodological purposes. As it is known, sound imitative vocabulary is widely used in daily communication by native speakers, which makes the speech lively, easy. It should be noted that insufficient attention is paid to the onomatopoeias, interjectives as not categorematic parts of speech, when mastering a foreign language.

Our practice shows that the learners of all skill levels are interested in onomatopoeia. Onomatopoeia will help German learning beginners to form interest in studying the language (words links becomes more obvious, which helps to learn), it will help people who continue learning German to enrich vocabulary, especially the expressive and evaluative vocabulary, as well as to eliminate some difficulties in the perception of German speech.

Onomatopoeias, as well as idioms and phraseological units with these words, can be included into a variety of exercises for development of pronunciation, speaking, listening skills. Many words of the language are "derived" from onomatopoeias on the basis of phonosemantic and etymological analysis. So, klappen "go well, be on the mend"; Klappe "mouth"; Klapperschlange 1) "rattlesnake"; 2) "talker, rattle, typist" and idiom Er hat einen Klaps "He is crazy" comes from klapp "impact sound, knock".

The materials of the Dictionary enable to significantly enlarge vocabulary and accelerate its replenishment due to phonosemantic associations. So, muh "mooing of a cows, bull"; muhen "moo (cow)"; mucken "moo (person)"; muffeln "mutter, grumble."

Such presentation of the material stimulates interest among trainees, facilitates mastering the meanings of lexical units from different spheres of existence, and enriches vocabulary by colloquial expressive-appraisive vocabulary. In addition, based on onomatopoeic vocabulary universal and specific features of German and Russian languages are clearly revealed, which certainly helps both to form intercultural competence, which is one of the most important tasks while teaching a foreign language, and more adequate translation.

\section{Conclusions}

1. In lexicographic fixation of onomatopoeias there are the following problems: a) insufficient and non-systemic lexicographical fixation of sound imitative words; b) indistinct system of field labels; c) undifferentiated onomatopoeias, interjections and sound symbolic words; $g$ ) insufficient etymological development of this lexical flayer; d) the lack of clear criteria for comparison in the bilingual dictionaries; e) the problem of translation of onomatopoeias in bilingual dictionaries. 
2. This Dictionary solves many problems: 1) fixes the primary material for creation of the future German phonosemantic dictionary; 2) provides material for etymologizing certain German lexemes; 3) enables to follow the development of certain semantic linguistic units, not only within the Roman-Germanic, but also IndoEuropean languages; 4) presents in the most general form the phono-sphere of the German language; 5) offers practical material for lexicographic, methodological and translation purposes.

3. Universal and specific phonosemantic principles of comparison of onomatopoeias in a bilingual dictionary have been revealed. The universal features include: acoustic features (bam - бам, bim - бим); phonemic identity

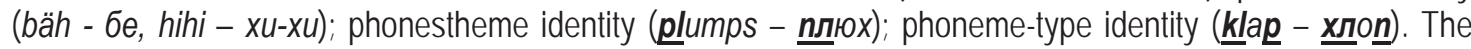
specific features include: phonestheme linguistic specificity (Ger. phonestheme / kn l: knack (s), knick (s), Knall - Rus. phonestheme/hr/, /trl: xpycm, треск); sound imitative motivation and etymology ("piercing-cutting" semantics: Germ. Die Klingen kreuzen "cross swords", measure strength (in a dispute) "- Russ. pyбumься, резаться на словах (to fight in word) "to argue" (colloquial); Обмен колкостями (the exchange of barbs) "dispute"). These principles give opportunity to find more exact correspondences in translation, even in the absence of the required unit in the Dictionary.

4. The structure of the Dictionary, phonosemantic principles of description of the sound imitative units taking into account their etymological origins and stylistic coloring, extensive illustrative material from literature, journalism and colloquial speech in German and Russian languages, a sufficiently great number of Russian equivalents allow professionals in phonosemantics, etymology, semantics, stylistics, word-formation of the German language to use the dictionary successfully.

\section{References}

Baranov, A. N. \& Kobozeva, I. M. (1988). Modal Particles in Answers to Questions, Pragmatics and the Problems of Intentionality. Moscow: IVAN USSR.

Baranov, A. N. (2001). Introduction to Applied Linguistics: Education Guidance. Moscow: Editorial URSS.

D'Elia R., Whissel C. \& Kneer R. (1989). The Dictionary of Affect in Children's Languages. Social and Behavioral Science Documents. Retrieved 25.07.14 from http://www.trismegistos.com/MagicalLetterPage/Bibliography.html

Denisov, P. N. (1980). Vocabulary of Russian Language and Principles of its Description. Moscow: Russian Language.

Dobrushina, N. R. (1995). Principles and Methods of Systematic Lexicographic of Interjections. PhD thesis. Moscow.

Dornseiff, F., Quasthoff, U. \& Wiegand, H. E. (2004). The German lexicon according to subject groups. Berlin; New York: de Gruyter.

Duden (2001). Original dictionary: Etymology of the German language. The history of German words to the present. 20,000 words and phrases in about 8000 articles. Mannheim; Leipzig; Vienna, Zurich: Duden Verl.

Duden (2007). German Universal Dictionary: The comprehensive explanatory dictionary of the German language. About 150000 keywords and phrases [Hardcover]. Mannheim; Leipzig; Vienna; Zurich: Duden Verl.

Duden. The Big Dictionary of German language in 10 volumes. on-line version for ABBYY Lingvo.

EWDS (2002). Etymological Dictionary of the German Language, Berlin: de Gruyter. CD-ROM.

Fasmer, M. (1986-1987). Etymology Dictionary of Russian Language: in 4 vol. Moscow: Progress, from http://www.dic.academic.ru/

Fujita, T. (1984). Wa-ei giongo/gitaigo honyaku jiten (Japanese/English: Mimesis/Onomatopoeia translation dictionary). Kinseidô; Tokyo, Retrieved 25.07.14 from http://www.trismegistos.com/MagicalLetterPage/Bibliography.html

Gomi, T. (1989). An illustrated Dictionary of Japanese Onomatoporetic Expressions. Tokyo: Japan Times, Retrieved 25.07.14 from http://www.trismegistos.com/ MagicalLetterPage/Bibliography.html.

Kakehi, H., Schourup, L. \& Tamori, I. A. (1998). Dictionary of Iconic Expressions in Japanese. Mouton, The Hague, Retrieved 25.07 .11 from http://www.ama-zon.com/Dictionary-Expressions-Japanese-Linguistics Documentation/dp/3110128101/

Kurashkina, N. A. (2007). Sound Denotations as Representation of the Sound Sphere in Language: on the material of English, French and Russian anthropo- and ornitho-phones. PhD thesis. Ufa.

Kveselevich, D.I. \& Sasina, V.P. (2001). Russian-English Dictionary of Interjections. Moscow: AST, Astrel.

Magnus, M. A. (1999). Dictionary of English Sound. Retrieved 12.07.14 from http://www.trismegistos.com/MagicalLetterPage/ Bibliography.html

Materials for Integrated Dictionary of Contemporary Russian Language (samples of dictionary entries). (1991). (Ed. 32). Moscow: All-Russian Institute of Scientific and Technical Information.

McCune, K. M. (1983). The Internal Structure of Indonesian Roots. University of Michigan. Retrieved 12.07.14 from http://www.trismegistos.com/ MagicalLetterPage/Bibliography.html

Melxhuk, I. A., Zholovsky A. K. \& Apresyan U. D. (1984). Explanatory and Combinatorial of Contemporary Russian Language. Experiences of Semantic-syntactical Description of Russian Vocabulary. Wien: Wiener Slavistischer Almanach, Retrieved 25.07.2012 from http://www.superlinguist.com/

Mischke, J. (2013). Multilingual lexicography and onomatopoeia: development of a bilingual dictionary German, English and Polish verbs noise. Retrieved 19.08.14 from http://www.akademikerverlag.de

Shlyakhova, S.S. \& Shestakova, O. V. (2011). German Onomatopoeia: history of study, problems, German-Russian Dictionary. Perm: National Research Polytechnic University.

Shlyakhova, S.S. (2004). Slash of the Language: The Dictionary of Russian Phono-Semantic Anomalies. Perm: Perm State Pedagogical University. 